\title{
Family Impact on Capital Structure: Does Financial Crisis Matter?
}

\author{
Inês Lisboa \\ (Polytechnic Institute of Leiria, 2411-901 Leiria, Portugal)
}

\begin{abstract}
This study analyses whether family control impacts the firm's capital structure and if results are influenced by financial turbulences. Using a sample of Portuguese listed firms during fourteen years, results show that family and-non family firms have different debt levels in periods of expansion. Moreover, the higher concentration of family ownership leads to reduction in the firm's leverage, especially in recession periods. These results confirm the behavioural-agency theory: the family looks to socio-emotional wealth but assuring the firm presence for future generations.
\end{abstract}

Key words: family firms; family control; F-PEC scale; capital structure; debt; financial crisis

JEL codes: G32, G34, E32

\section{Introduction}

Capital structure thematic appeared in 1958 with Modigliani and Miller. Since then it has been greatly researched. Diverse theories appeared to explain the optimal capital structure: trade-off, pecking-order, and agency-cost theories. Although results are mixed and inconclusive, which can be caused by diverse factors such as the country analyzed, firm's own characteristics, among others (Fauzi et al., 2013). In this study I analyze the impact of family control on the firm's capital structure. Within this line of research, several papers exist which provide evidence about the impact of family on the firm's capital structure (Anderson et al., 2003; King \& Santor, 2008; Margaritis \& Psillaki, 2010; Croci et al., 2011; Schmid, 2012; Fauzi et al., 2013).

I shed new light in this topic by analysing if the impact of family firms on financial decisions is influenced by expansion or recession periods. I also analyse if the family control impacts the level of firm's leverage. This study contributes to the existing body of empirical literature in three ways. First I analyze the Portuguese case, a small-sized market that is gaining prominence in the Europe and worldwide. Family firms represent around 70-80\% of the Portuguese firms, and $50 \%$ of the PSI-20, the stock market index formed by the twenty largest and most liquid firms quoted on the Portuguese market. Most studies have been carry out to major countries as U.S. market, Europe, France, Germany, New Zealand, among others. In this sense this study will expand international evidences and allow comparisons with other data sets, which should be quite useful for investors, managers and researchers.

The second contribution is related to the ways proposed to measure the family impact on the firm capital structure. In a first step, I classify family firms using the "family controlled" definition: a family firm is a company that is owned and controlled by a family. Then I use two alternative measures of the family influence: the percentage of family ownership and the F-PEC scale of Astrachan et al. (2002). The F-PEC scale includes

Inês Lisboa, Professor, School of Technology and Management, Management for Sustainability Research Centre, Polytechnic Institute of Leiria; research areas/interests: finance, corporate governance, family firms. E-mail: ines.lisboa@ipleiria.pt. 
three subscales: power, experience and culture, assuring that family identity in the firm. As far as I am aware, this way to measure the family control has not been previously addressed on capital structure literature.

Finally, I also include the impact of market cycles to this analysis. I analyze a period of fourteen years, with extreme down market periods and extreme up market periods. Firms may react differently in expansion and contraction periods. In expansion periods, firms may not only be concerned with the firm maximization but also with some personal benefits, as reputation, social status. In recession periods, the conflict of interests between major and minority shareholders and also between shareholders and debt holders may increase. These differences in results can be enhanced to family firms since, regarding the behavioral-agency theory, the family desire to maintain socio-emotional wealth, but assuring the firm's performance and survival.

The main results show that market cycles does matter to explain the family impact on the firm financial decisions. Family firms present higher debt levels, compared to non-family firms, in expansion periods, but similar debt levels in recession periods. Moreover, family and non-family firms leverage is influenced by different variables. Higher concentration of family ownership leads to lower debt levels, especially in recession periods. These findings corroborate the need of family control and to avoid agency costs. These findings are especially relevant for institutional and individual investors in a national and international context, academics, and the professional managers of these companies.

The remainder of the article is organized as follows. Section 2 presents the theoretical background and the hypothesis of this study. Section 3 describes the methodology employed. Section 4 describes the sample data and summary statistics. Section 5 contains empirical results. Finally, Section 6 has concluding remarks.

\section{Theoretical Background}

\subsection{Family Firm Definition}

Berle and Means highlight the importance of ownership structures on the firm in 1932. Since then, diverse researchers have focused their attention on this field, especially on family firms. Although, there are numerous definitions of family firms, which makes it difficult to compare different studies (Miller et al., 2007). Analyzing a large list of family firms' concept I find two fundamental elements: ownership and management. In this study I focus the definition on "family controlled", since in Portugal, the family's identity and culture is present whenever the family has an impact on the firm ownership and management. I looked for the firm's history to assure the family involvement. Contrary to some studies, I did not establish a minimum threshold for family ownership. I consider it is not an important goal in this work, because I use family ownership as variable to analyze the impact of the family involvement in the firm's capital structure. Moreover, according to Martín-Reyna and Duran-Encalada (2012), the cultural and legal contexts, which differ from country to country, are contingent on family business. Consequently family firm is defined as a company owned and controlled by a family. This definition is similar to that of Anderson and Reeb (2003), and Villalonga and Amit (2006).

\subsection{Research Focus and Hypothesis}

The firms can use two common types of financing: equity and debt (Fauzi et al., 2013). Each type of financing has its own advantages and limitations when compared to one another. In 1958 Modigliani and Miller argued that firms have benefits to use debt, namely tax savings. Although, using debt also have costs such as bankruptcy and agency costs (De Angelo \& Masulis, 1980; Jensen \& Meckling, 1976). These assumptions lead to the trade-off theory: to maximize the firm value, the firm tries to find the optimal capital structure, which is a 
combination of debt and equity. Moreover, the dynamic pecking order theory created by Myers (1984) and Myers and Majluf (1984) indicate that stakeholders will not apply their funds in the firm when information asymmetry is high. The CEO knows the firm value and potential, but financial investors may not perceive the firm's real value due to the lack of information, which may lead to irrational decisions.

These theories: tax savings, bankruptcy costs, agency costs and information asymmetry are relevant to explain family firms. Family firms present singular characteristics compared to non-family firms, which can justify the differences in the firm's capital structure. The family, especially the founder, sees the firm as an extension of his wealth (Anderson \& Reeb, 2003). Therefore the family personal risk is intrinsic to the firm risk. Moreover, the family is not only concerned to maximize the firm value, but also with the family socio-emotional wealth (behavioral-agency theory of Gomez-Mejia et al., 2007). To sustain the firm presence in the market and pass on the firm to future generation, the family avoids external capital since it leads to higher risk of failure, especially in recession periods.

The firm control is usually present in this type of firms. The family is not only an investor but is also present in the board of directors. To fill the need to exercise the family influence, the family has an incentive to control managers' opportunism, when the CEO is not a family member. Thus the classical agency problem of Jensen and Meckling (1976), between the principal and the agent, is mitigated or at least reduced. The family also avoids agency costs between the principal and the debt providers (Schmid, 2012). To sustain the firm's control and to avoid financial distress the family looks for internal capital or to family financing. The family control leads to concentration of information about the firm: aims, strategy, value, financial potential. As family firms' information is scarce and less transparent it may be difficult to creditors to offer opportunities of financing. Moreover, due to the family control, these firms have less need to pay out dividends, which in turn leads to increase internal financing potential (Schmid, 2012).

Even if using debt can generate tax saving, the family has innumerous reasons to avoid it due to the fear of risk taking, especially in recession periods. Schmid (2012) found that the family adjusts the capital structure to work in the family favor. While in expansion periods some family needs may be accomplish, in recession periods the family may avoid risky decision in order to sustain the firm presence in the market (Gomez-Mejia et al., 2007).

When comparing family and non-family firms, the conclusions are not unique. Anderson et al. (2003), for instance, did not find differences in the debt structure of family and non-family firms, when analyzing U.S. firms. For another side, King and Santor (2008) found that Canadian family firms present higher debt ratios than non-family firms. Margaritis and Psillaki (2010), Croci et al. (2011), and Schmid (2012) found the opposite results to France, Europe, and Germany, respectively.

Taken together, these arguments suggest the following hypothesis:

Hypothesis 1: Family firms' capital structure is different from that of non-family ones, and this relation is influenced by market cycles.

Family firms are not a homogeneous group. As a result, the firm's capital structure may be influenced by family involvement in the firm. For one side, family ownership concentration may reinforce the need for control, avoid distress costs, reduce the firm risk, and make information scarcer to financial investors and debt providers. For another side, the long-term survival, and the long investment horizon leads to relationships of trust and loyalty between the family owners and debt providers (Schulze et al., 2003). Thus the family may have less debt financing costs and may look more for outside financing. 
Portugal is a country where the tradition and reputation are important, so I expect that when the family ownership increases, the firm's leverage decrease, especially in recession periods when the firm's survival can be questioned. As a result, the following hypothesis naturally follows:

Hypothesis 2: Higher family control reduces the level of debt, especially in recession periods.

\section{Methodology}

I use panel data methodology since it allows me to detect the individual firm's impact, to control for unexpected heterogeneity, which is usual in governance issues, and for potential endogeneity problems between ownership structure and capital structure (Pindado et al., 2008). I use the GMM (Generalized Method of Moments) approach of Mackinlay and Richardson (1991) to estimate the models proposed. Following Pindado et al. (2008), I use as instrumental variables the ones at the right hand side of the equations.

To measure the impact of family business on the firm capital structure (hypothesis 1) I regress the following model:

$$
\begin{aligned}
\text { Leverage }= & \alpha_{t}+\beta_{1} \times D \text { fam }_{t}+\beta_{2} \times \text { Growt }_{t}+\beta_{3} \times \text { Size }_{t}+\beta_{4} \times \text { Age }_{t}+\beta_{5} \times R O A_{t}+\beta_{6} \times S . G_{\cdot t}+\beta_{7} \\
& \times M T B V_{t}+\beta_{8} \times \text { Risk }_{t}
\end{aligned}
$$

The firm's leverage is regressed against the dummy variable, which is one when the firm is a family firm and zero otherwise. I also include some control variables: firm's growth, size, age, ROA, sales growth, MTBV, and risk. This model is similar to that of Croci et al. (2011) and Schmid (2012).

To better understand the family firms, one of the study aims, I define the following model:

$$
\begin{aligned}
\text { Leverage }= & \alpha_{t}+\beta_{1} \times \% \text { Fam }_{t}+\beta_{2} \times \text { Growth }_{t}+\beta_{3} \times \text { Size }_{t}+\beta_{4} \times \text { Age }_{t}+\beta_{5} \times \text { ROA }_{t}+\beta_{6} \times S . G_{\cdot t}+\beta_{7} \\
& \times M T B V_{t}+\beta_{8} \times \text { Ris }_{t}+\beta_{9} \times \text { Drrisis }_{t}
\end{aligned}
$$

This model is test only to family firms. I use two ways to measure the family ownership (\%Fam): percentage of the family equity (\%Ow) and the F-PEC scale, which contains three subscales: power, experience and culture.

The models are regressed three times: first using the whole sample and then the sample is divided in two: one including the periods of recession, and other with the expansion periods.

Following previous literature I expect the following relationship between leverage and the variables included in the models:

Table 1 Expected Signs

\begin{tabular}{|l|l|l|}
\hline Variable & Expected Sign & Previous studies \\
\hline Dfam & - & Margaritis and Psillaki (2010), Croci et al. (2011), Schmid (2012) \\
\hline \%Fam & - & Jensen and Meckling (1976), Gomez-Mejia et al. (2007) \\
\hline Growth & - & Jensen (1986), Fauzi et al. (2013) \\
\hline Size & + & Croci et al. (2011), Fauzi et al. (2013) \\
\hline Age & - & Schmid (2012) \\
\hline ROA & - & Croci et al. (2011), Schmid (2012), Fauzi et al. (2013) \\
\hline S.G. & + & Croci et al. (2011), \\
\hline MTBV & - & Croci et al. (2011), Schmid (2012) \\
\hline Risk & + & Modigliani and Miller (1963) \\
\hline Dcrisis & + & --- \\
\hline
\end{tabular}

Note: Expected relationship (+ positive or - negative) between the debt ratio and the variables included in the sample, and previous studies that suggest that relationship. 


\section{Sample Data}

This study focuses on a Portuguese dataset, namely the listed firms of Euronext Lisbon over a sample period of fourteen years, starting on January 1999, the date of the introduction of the euro, until December 2012. I study a single country - Portugal, for several reasons. First, family firms - a primary focus on this study, are a norm rather than an exception in Portugal. Around $70-80 \%$ of Portuguese firms and half of the Portuguese listed firms are family firms. Second, it is a small-sized financial market almost unexplored but with a growing importance in the world financial market. In regards to financial turbulences, Portugal is a country in vogue since it asks troika's help to reduce the country's economic deficit and sustain is future finance. Third, the majority of studies relating family firm issues are headquartered in the U.S., and major European countries, neglecting other regions. Analyzing Portugal is a way to expand international evidence and to enable comparisons of existing results for major countries to understand if conclusions are international evidence. Finally, analyzing a single country allows to examine the country-specific characteristics, and the macro and development economic stages, the accounting standards, and the corporate governance environment is the same. Joh (2003) says that a cross-country analysis can underestimate the importance of the country-specific laws.

First I collect ownership data, namely the names of the firm's owners, of the members of the board of directors and of the supervisory board for each year in analysis. Then I manually classify firms into family and non-family. A firm is classified as a family firm whenever there is fractional equity ownership of the founding family and the presence of family members on the board of directors. All the others are non-family firms. Firms which changed from family to non-firms or vice-versa were deleted.

I introduce the family impact on the capital structure using a dummy variable, which is one when the firm is a family firm and zero otherwise (Dfam). Moreover I analyze if, to family firm, the family involvement impacts the firm capital structure using the percentage of the family ownership (\%Ow) and the F-PEC scale (F-PEC) introduced by Klein (2000) and then developed by Astrachan et al. (2002):

$$
F a m(F-P E C)=\left(\frac{E Q_{F a m}}{E Q_{\text {total }}}\right)+\left(\frac{B o D_{F a m}}{B o D_{\text {total }}}\right)+\left(\frac{S B_{\text {Fam }}}{S B_{\text {total }}}\right)
$$

Where: EQ is the family equity ownership, $\mathrm{BoD}$ is the proportion of family members on the board of directors over the total members, and SB is the proportion of family members on the supervisory board over the total members. Table 2 presents the sample structure.

Table 2 Sample Structure

\begin{tabular}{lll}
\hline Panel A: Total Sample & & \\
\hline & Family & Non-Family \\
\hline Number of firms (mean) & 37 & 41 \\
Number of observations (total) & 383 & 367 \\
\hline Panel B: Family Firms & & - \\
\hline F-PEC scale & $71.55 \%$ & - \\
\% family ownership & $36.52 \%$ & \\
\hline
\end{tabular}

Note: Panel A presents the average number of firms and the total number of observations (from 1999 to 2012) of family and nonfamily firms included in the sample. Family firms are firms owned and controlled by a family. Panel B presents the mean value of the family involvement in family firms measured by the F-PEC scale and the family ownership.

The number (mean) of family firms is lightly smaller than the number of non-family firms. Although, 
analyzing the number of observations, it is higher to family firms, suggesting that family firms are older and more prevalent than non-family ones. In what regards to family involvement, the percentage is significantly higher using the F-PEC scale. This fact suggests that the presence of the family in the boards of directors is high, since to Portugal the supervisory board should be an independent board of the board of directors. Thus, the family may not have a higher concentration of ownership, but they control the board of directors and so their identity and culture is present, as I expected.

The financial data collected allowed me to calculate the dependent variable and also some control variables to deal with firm's characteristics. The firm leverage is the firm total debt over the total assets; the firm growth is the annual growth of the total assets; the firm size is the natural logarithm of the firm's assets; the firm age is the number of years since its foundation until the year of analysis; the ROA is the firm's return on asset; the sales growth (S.G.) is the annual growth of the total sales; the MTBV is the firm market-to-book value; the risk is the standard deviation of the firm 12 months return.

Table 3 Summary Statistics

\begin{tabular}{|c|c|c|c|c|c|c|c|c|}
\hline \multicolumn{9}{|c|}{ Panel A: Descriptive Statistics } \\
\hline & Leverage & Growth & Size & Age & ROA & SG & MTBV & Risk \\
\hline Mean & 0.2998 & 0.1336 & 5.6174 & 12.3719 & 0.0129 & 0.1890 & 1.7208 & 0.0311 \\
\hline Median & 0.2982 & 0.0453 & 5.5561 & 12.000 & 0.0174 & 0.0539 & 1.1500 & 0.0215 \\
\hline Max. & 17.1195 & 7.6048 & 7.9970 & 25.000 & 0.6788 & 24.379 & 34.3400 & 0.3519 \\
\hline Min. & -0.5852 & -0.9990 & 2.4314 & 1.0000 & -1.1819 & -0.9998 & -96.1200 & 0.0000 \\
\hline Std. Dev. & 0.6562 & 0.4446 & 1.0111 & 5.7460 & 0.1002 & 1.2014 & 4.7503 & 0.0344 \\
\hline Skew. & 22.9634 & 8.2276 & 0.0943 & -0.0208 & -3.0900 & 15.7018 & -10.5037 & 4.2289 \\
\hline Kurtosis & 589.6051 & 118.1084 & 2.9808 & 2.3062 & 43.8760 & 286.1025 & 254.7670 & 28.1539 \\
\hline \multicolumn{9}{|c|}{ Panel B: Difference of the mean values } \\
\hline & Leverage & Growth & Size & Age & ROA & SG & MTBV & Risk \\
\hline Family & 0.2906 & 0.1459 & 5.5761 & $12.820^{* *}$ & $0.0212^{* *}$ & 0.2220 & 1.6073 & 0.0303 \\
\hline Non-family & 0.3097 & 0.1203 & 5.6625 & 11.8832 & 0.0039 & 0.1530 & 1.8447 & 0.0321 \\
\hline \multicolumn{9}{|c|}{ Panel C: Correlation Matrix } \\
\hline & Leverage & Growth & Size & Age & ROA & SG & MTBV & Risk \\
\hline Leverage & 1 & & & & & & & \\
\hline Growth & -0.0902 & 1 & & & & & & \\
\hline Size & 0.0676 & 0.0551 & 1 & & & & & \\
\hline Age & -0.0232 & -0.1922 & -0.1165 & 1 & & & & \\
\hline ROA & -0.0748 & 0.2242 & 0.0907 & -0.0116 & 1 & & & \\
\hline SG & -0.0344 & 0.1265 & -0.0873 & -0.0562 & 0.0339 & 1 & & \\
\hline MTBV & -0.0111 & 0.0748 & 0.0836 & -0.1062 & 0.0136 & 0.0054 & 1 & \\
\hline Risk & -0.0258 & -0.0432 & -0.3208 & 0.2252 & -0.1715 & 0.0177 & -0.0899 & 1 \\
\hline
\end{tabular}

Note: Panel A presents descriptive statistics, namely mean, maximum, minimum, standard deviation, skewness and kurtosis, for the variables include in the model: leverage is de total debt over the total assets, growth is the annual growth of the total assets, size is the natural logarithm of the firm's assets, age is the number of years since the firm foundation until the year of analysis, ROA is the firm's return on asset, sales growth is the annual growth of the total sales, MTBV is the firm market-to-book value, and risk is the standard deviation of twelve months return. Panel B present the mean values of these variables to family and non-family firms. Panel $\mathrm{C}$ reflects the correlation matrix for all these variables. ${ }^{*}, * * * * *$ indicate a difference in means between family and nonfamily firms at the $1 \%, 5 \%$ and $10 \%$ significance levels, respectively. 
To identify market cycles I analyze the PSI20 return, following Dessender (2010). Periods of a negative stock market were considered as recession periods, whether periods of positive stock market were considered periods of expansion. I identified six crisis periods. The PSI20 dropped $11.20 \%$ during the year of 2000 due to the dot-com bubble burst. Latter, in 2001, it fell 26.5\% as a consequence of the 9 September attack, and in 2002, 26.2\% due to the corporate scandals. More recently, in 2008 the Lehman and Brothers collapse, followed by the Portuguese banks: Banco Português de Negócios and Banco Privado Português, caused a drop of $66.3 \%$ of the PSI20. In 2010 the Portuguese public deficit caused a fall of 8.9\% in the PSI20, and, in 2011, 31.2\% due to the contraction measures applied by the Toika organism. The expansion/recession periods are similar to those presented by Castro (2011b).

Once the dataset is described, I present the summary statistics of the study variables in Table 3. Panel A shows descriptive statistics: mean, maximum, minimum, standard deviation, skewness and kurtosis. Panel B show the mean value of the variables to family and non-family firms and the t-statistic of the difference of the mean test. Panel C shows the correlation coefficients.

The following facts emerge from Table 3: (1) In mean, the firms in the sample only finance $30 \%$ of their assets with debt. Results are similar to family and non-family firms, but the first group present, in average, less debt. (2) The firms included in the sample present, in average, positive assets and sales growth, ROA and MTBV. (3) In average, family firms are older and have higher return on assets than non-family firms. (4) None of the variables included in the models are highly correlated, at least not to a significant extent. (5) The correlation between leverage and the others variables present the expected signs, except the sales growth and firm risk. These facts suggest that firms need to look for external capital to finance its sales growth and the firm financial risk is not the major part of the firm risk.

\section{Empirical Results}

Table 4 presents results from the tests of the first model proposed: regression of the firm's leverage against a dummy variable which is one when the firm is family type and zero otherwise and additional control variables.

Table 4 Family Impact on Capital Structure

\begin{tabular}{|c|c|c|c|c|c|c|c|c|c|}
\hline & \multicolumn{3}{|c|}{ Total Period } & \multicolumn{3}{|c|}{ Recession Period } & \multicolumn{3}{|c|}{ Expansion Period } \\
\hline & Total & Family & Non-Family & Total & Family & Non-Family & Total & Family & Non-Family \\
\hline $\mathrm{C}$ & 0.1229 & $-0.1728 * * *$ & 0.5210 & 0.5879 & -0.1569 & $1.3386 *$ & $-0.2633 * * *$ & $-0.1653 *$ & $-0.1739 * *$ \\
\hline $\mathrm{D}_{\text {Fam }}$ & -0.0016 & - & - & -0.0758 & - & - & $0.0546 * * *$ & - & - \\
\hline Growth & $-0.1225 * *$ & $0.0544 * * *$ & $-0.5168 * * *$ & $-0.2465 * *$ & $0.0673 * *$ & $-1.0191 * * *$ & $0.0515 * *$ & $0.0547 *$ & 0.0220 \\
\hline Size & $0.0456 *$ & $0.0960 * * *$ & -0.0094 & -0.0164 & $0.0895 * * *$ & -0.0912 & $0.0996 * * *$ & $0.0981 * * *$ & $0.0814 * * *$ \\
\hline Age & -0.0036 & $-0.0059 * * *$ & -0.0023 & -0.0051 & $-0.0051 * *$ & -0.0154 & $-0.0030 *$ & $-0.0067 * * *$ & 0.0016 \\
\hline ROA & $-0.4195 *$ & $-1.2561 * * *$ & -0.0682 & -0.0545 & $-1.4934 * * *$ & 0.0174 & $-0.7273 * * *$ & $-1.1833 * * *$ & $-0.4726 * * *$ \\
\hline S.G. & -0.0093 & $-0.0117 * *$ & 0.0411 & -0.0240 & $-0.0162 *$ & 0.0088 & -0.0078 & -0.0094 & -0.0075 \\
\hline MTBV & -0.0020 & -0.0005 & -0.0009 & 0.0005 & 0.0050 & -0.0020 & -0.0022 & -0.0028 & -0.0020 \\
\hline Risk & -0.2244 & $0.8619 * * *$ & -2.2800 & -0.7191 & $0.8414 *$ & -2.9599 & 0.0660 & $0.8559 * *$ & $-1.1982 * * *$ \\
\hline Observations & 734 & 383 & 351 & 326 & 168 & 158 & 408 & 215 & 193 \\
\hline Adj-R square & $0.80 \%$ & $39.93 \%$ & $1.75 \%$ & $0.31 \%$ & $40.33 \%$ & $3.38 \%$ & $31.12 \%$ & $38.47 \%$ & $29.23 \%$ \\
\hline
\end{tabular}

Note: This table presents the estimates of leverage (total debt over total assets) on a dummy variable which equals to one when the firm is family type, and zero otherwise $\left(\mathrm{D}_{\text {Fam }}\right.$ ), and control variables: growth (annual growth of the total assets), size (natural logarithm of the firm's assets), age (number of years since the firm foundation until the year of analysis), ROA (firm's return on asset), sales growth (annual growth of the total sales), MTBV (firm market-to-book value), risk (standard deviation of twelve months return). Results are present to the total sample, Family Firms and Non-Family firms, and to the total period, recession period and expansion period. *, **, *** Significant at the $10 \%, 5 \%$ and $1 \%$ levels, respectively. 
My first hypothesis is validated. During crisis family firms do not behave differently than non-family firms in terms of debt. In recession periods, all firms are financially constrained and have additional stress due to financial turbulences. Therefore firms avoid financial risk of increasing debt levels, independently of the type of shareholders. Similar conclusion where found by Anderson and Reeb (2003) when analyzing listed U.S firms, but ignoring the crisis effect, and to Lins et al. (2013) when analyzing 35 countries. In expansion periods results are different. Family firms present higher debt levels, contrary to my expectation. May be due to long term relationships with debt providers, family firms look for debt not only to invest in the firm and maximize its value but also to provide the family with socio-emotional wealth. These conclusions are consistent with the behavioral-agency theory of Gomez-Mejia et al. (2007).

Moreover the model estimated is more accurate to explain the family firms' leverage, and to periods of expansion. In recession periods there are macroeconomic factors that may influence more shareholders behavior in regards to capital structure than the firm's characteristics. There are some differences in regards to the control variables included to explain family and non-family firms' leverage. While to family firms the assets growth causes a positive impact on the debt ratio, to non-family firms I find the opposite relation. Family firms look for debt to finance the firm's expansion and increase the assets. In fact to grow firms need capital and internal capital is usually insufficient. As family firms are afraid to lose the firm control, the family prefers to look for debt than to increase equity and look for new investors. Non-family firms have the opposite reaction, they prefer to go to the stock market and look for new investors. This not only allows them to have access to funds with lower cost but also to acquire more prestige in the financial market.

The firm size and risk are relevant to positively explain the family firm leverage, but are insignificant in regards to non-family firms. Same conclusion is found to age, ROA and sales growth, but these variables have a negative impact in family firms' capital structure. Non-family firms' debt is influenced by different variables than that of family firms may be due to the singular characteristics of family firms which set them apart of non-family firms. To expand the firm's size, family firms need to invest in new and innovative projects and therefore need capital. As explained before, family firms prefer debt to own shares, so the firm size positively impacts the debt ratio. As the leverage increases, the financial risk also increases and thus the firm total risk is higher. Older family firms, with higher returns and sales growth have more self-financing and so do not need to look for debt to finance their business.

To better understand family firms, I analyze the family control impact on the firm's capital structure. To that end, I analyze the model 2 characterized by introducing a percentage of the family control: family ownership and F-PEC scale. Results are present in Table 5.

Analyzing Table 5 I prove the validity of the second hypothesis: higher family ownership causes a negative impact in the firm leverage, especially in recession periods. When the family involvement in the firm increases, the family tends to present less debt. The family prefers to use internal financing to avoid agency problems with debt providers and the loss of control. This conclusion is similar with that of Fauzi et al. (2013). It is important to point out that family impacts on the firm leverage is only proved when I measure the family control using the family ownership. In regards to the F-PEC scale, the family control is statistically insignificant to explain the firm's leverage, may be because the afraid of losing control is related with family ownership instead of the family management. The significance of control variables are the same presented afore. 
Table 5 Family Control Impact on Capital Structure

\begin{tabular}{|c|c|c|c|c|c|c|}
\hline & \multicolumn{2}{|c|}{ Total Period } & \multicolumn{2}{|c|}{ Recession Period } & \multicolumn{2}{|c|}{ Expansion Period } \\
\hline & F-PEC & \%Own & F-PEC & $\%$ Own & F-PEC & $\%$ Own \\
\hline $\mathrm{C}$ & $-0.1520 * *$ & $-0.1542 * *$ & -0.1309 & -0.1292 & -0.1482 & -0.1511 \\
\hline$\%$ & -0.0224 & $-0.0008 * *$ & -0.0277 & $-0.0011 * *$ & -0.0187 & -0.0006 \\
\hline Growth & $0.0550 * * *$ & $0.0547 * * *$ & $0.0692 * *$ & $0.0712 * * *$ & $0.0543 *$ & 0.0526 \\
\hline Size & $0.0948 * * *$ & $0.0968 * * *$ & $0.0878 * * *$ & $0.0898 * * *$ & $0.0971 * * *$ & $0.0990 * * *$ \\
\hline Age & $-0.0057 * * *$ & $-0.0053 * * *$ & $-0.0049 * *$ & $-0.0042 *$ & $-0.0065 * * *$ & $-0.0063 * * *$ \\
\hline ROA & $-1.2618 * * *$ & $-1.2910 * * *$ & $-1.5072 * * *$ & $-1.5741 * * *$ & $-1.1872 * * *$ & $-1.2061 * * *$ \\
\hline S.G. & $-0.0115 * *$ & $-0.0110 * *$ & -0.0153 & -0.0135 & -0.0095 & -0.0095 \\
\hline MTBV & -0.0004 & -0.0009 & 0.0053 & 0.0053 & -0.0027 & -0.0033 \\
\hline Risk & $0.8401 * * *$ & $0.8313 * * *$ & $0.8084 *$ & $0.7583 *$ & $0.8429 * *$ & $0.8537 * *$ \\
\hline Observations & 383 & 383 & 168 & 168 & 215 & 215 \\
\hline Adj-R square & $39.86 \%$ & $40.52 \%$ & $40.08 \%$ & $41.35 \%$ & $38.23 \%$ & $38.64 \%$ \\
\hline
\end{tabular}

Note: This table presents the estimates of leverage (total debt over total assets) on family control measured by the F-PEC scale and the percentage of the family ownership, and control variables: growth (annual growth of the total assets), size (natural logarithm of the firm's assets), age (number of years since the firm foundation until the year of analysis), ROA (firm's return on asset), sales growth (annual growth of the total sales), MTBV (firm market-to-book value), risk (standard deviation of twelve months return). Results are present to the total period, recession period and expansion period. *, **, *** Significant at the $10 \%, 5 \%$ and $1 \%$ levels, respectively.

\section{Conclusions}

Family firms are present all over the world playing a crucial role, not only because they generate wealth to economies but also because they create job. The singularities of family firms set them apart from non-family firms. Although few works attempt to understand the financing decisions of family public firms.

This study focuses on the analysis of family control impact on the firm's capital structure, including the market cycle effect. The aim of this work is to analyze family and non-family firms capital structure differences and if the percentage of family ownership and control influence the firm's debt level. Moreover, I analyze whether family and non-family firms react differently in recession and expansion periods.

The contribution of this study is three-fold. Firstly, I analyzed a small and unknown market as is the Portuguese one, almost unexplored in corporate governance and financial issues. Around one-half of PSI-20 and of all listed firms are family firms, which brings relevance to this study. Moreover, this small-scale market present some singularities compared to Anglo-Saxon and major European market, to which most studies have been carry out. Secondly, I not only use a dummy variable to analyse the differences between family and non-family firms, but I also used two alternative variables to measure the family control: the family ownership and the F-PEC scale. This allows me to detect if the type of family control has impact on financial sources selected. Third, I introduce the market cycle effect. I analyze whether family and non-family firms behave differently in expansion and turbulent periods. The security of the Portuguese financial system was questioned in 2010, and consequently the country looked for 'Troika's' help to solve its financial problems. Likewise, analyzing the impact of financial crisis in the firm's leverage and understand which firms use more debt in recession and expansion periods is an important issue. 
Our overall results show that market cycles does matter to explain the family impact on the firm capital structure. In expansion periods family firms present higher leverage than non-family firms. This fact suggests that the family may look for debt to invest more and to, not only maximize the firm value, but also acquire reputation and other benefits to the family. During recession periods, family and non-family firms present similar debt levels. The additional stress resulting from the crisis limits the investment and the financial decisions of both types of firms in order to sustain their presence in the market. Although the reasons that explain why the family and non-family firms look for debt are different, confirming the singular characteristics of each type of firm. Family firms with a large size, more risk, young, with less return and sales growth need to look for debt to make new investments and sustain the firm presence in the market. Regarding family firms, higher concentration of family ownership leads to lower debt levels, especially in recession periods. When the family personal risk is more intrinsic to the firm risk, the family may have more conservative behavior in order to avoid risk and sustain the firm's presence for future generations.

These findings corroborate the results of Scmid (2012), Fauzi et al. (2013) and Lins et al. (2013), and also support the behavioral agency theory. In recession periods, when family ownership is more concentrate, the family avoids risk to assure the firm survival. Although, in expansion periods, the family may look for debt also to accomplish some personal socio-emotional wealth as status, reputation, higher salaries, among others.

Results are especially relevant not only for institutional and individual investors in a national and international context but also for academics and the professional managers of these companies. Investors may recognize why firms look for debt to finance their assets and its impact in the firm's risk level. Academics have a study of capital structure of a new country, and with new variables and a new and relevant effect: market cycle, which can explain why previous results are mixed and inconclusive. Finally, professional manager, especially the ones of family firms may understand that looking for debt brings also advantages to firms and not only limitations as agency costs and loss of control.

\section{References:}

Anderson R., Mansi S. and Reeb D. (2003). “Founding family ownership and the agency cost of debt”, Journal of Financial Economics, Vol. 68, pp. 263-285.

Anderson R., and Reeb D. (2003). "Founding-family ownership, corporate diversification, and firm leverage”, Journal of Law and Economics, Vol. 46, pp. 653-684.

Arellano M. and Bond S. (1991). "Some tests of specification for panel data: Monte carlo evidence and an application to employment equations”, The Review of Economic Studies, Vol. 58, No. 2, pp. 277-297.

Bhandari L. (1988). "Debt/equity ratio and expected common stock returns: Empirical evidence”, Journal of Finance, Vol. 43, pp. 507-528.

Berle A. and Means G. (1932). The Modern Corporation and Private Property, Hancourt, Brace \& World, Inc. Copyright, New York (Republished 1968).

Bengoechea P. and Perez-Quirós G. (2004). “A useful toot to identify recessions in the Euro-area”, Banco de Espana, Working paper 0419.

Castro V. (2011a). “The Portuguese business cycle: Chronology and duration dependence”, NIPE Working Paper, 11/2011, pp. 1-34.

Castro V. (2011b). “The Portuguese stock market cycle: Chronology and duration dependence”, NIPE Working Paper, 13/2011, pp. $1-17$.

Croci E., Doukas J. and Gonenc H. (2011). “Family control and financing decisions”, European Financial Management, Vol. 17 , No. 5, pp. 860-897.

De Angelo H. and Masulis R. (1980). “Optimal capital structure under corporate and personal taxation”, Journal of Financial Economics, Vol. 8, No. 1, pp. 3-29.

Desender K. (2010). “Ownership structure and stock price performance during turbulent financial markets”, AAA 2009 Financial 
Accounting \& Reporting Section (FARS) Meeting.

Faccio M. and Lang L. (2002). “The ultimate ownership of Western European corporations”, Journal of Financial Economics, Vol. 65, pp. 365-395.

Fauzi F., Basyith A. and Idris M. (2013). “The determinants of capital structure: An empirical study of New Zealand-listed firms”, Asian Journal of Finance \& Accounting, Vol. 5, No. 2, pp. 1-21.

Gomez-Mejia L., Haynes K., Nuñez-Nickel M., Jacobson K. and Moyano-Fuentes J. (2007). "Socioemotional wealth and business risks in family-controlled firms: Evidence from Spanish olive oil mills”, Administrative Science Quarterly, Vol. 52, pp. $106-137$.

Jensen M. (1986). “Agency costs of free cash flow corporate finance and takeovers”, American Economic Review, Vol. 76, No. 2, pp. 323-329.

Jensen M. and Meckling W. (1976). “Theory of the firm: Managerial behavior, agency cost and ownership structure”, Journal of Financial Economics, Vol. 3, pp. 305-360.

Joh S. (2003). “Corporate governance and firm profitability: Evidence from Korea before the economic crisis”, Journal of Financial Economics, Vol. 68, pp. 287-322.

King M. and Santor E. (2008). "Family values: Ownership structure performance and capital structure of Canadian firms”, Journal of Banking and Finance, Vol. 32, No. 11, pp. 2423-2432.

Klein S. (2000). “Family business in Germany: Significance and structure”, Family Business Review, Vol. 13, No. 3, pp. $157-181$.

La Porta R., Lopez-de-Silanes F. and Shleifer A. (1999). “Corporate ownership around the world”, Journal of Finance, Vol. 54, pp. 471-517.

Lins K., Volpin P. and Wagner H. (2013). “Does family control matter? International evidence from the 2008-2009 financial crisis”, Review of Financial Studies, Vol. 26, No. 10, pp. 2583-2619.

Mackinlay A. and Richardson M. (1991). "Using generalized method of moments to test mean-variance efficiency”, Journal of Finance, Vol. 46, pp. 511-527.

Margaritis D. and Psillaki M. (2010). “Capital structure, equity ownership and firm performance”, Journal of Banking and Finance, Vol. 34, No. 3, pp. 621-632.

Martin-Reyna J. and Duran-Encalada J. (2012). "The relationship among family business, corporate governance and firm performance: Evidence from the Mexican stock exchange”, Journal of Family Business Strategy, Vol. 3, pp. 106-117.

Miller D., Breton-Miller I., Lester R. and Cannella Jr A. (2007). “Are family firms really superior performers?”, Journal of Corporate Finance, Vol. 13, pp. 829-858.

Modigliani F. and Miller M. (1958). “The cost of capital, corporation finance and the theory of investment”, American Economic Review, Vol. 48, No. 3, pp. 261-297.

Modigliani F. and Miller M. (1963). “Corporate income taxes and the cost of capital: A correction”, American Economic Review, Vol. 53, pp. 433-443.

Myers S. (1984). “The capital structure puzzle”, Journal of Finance, Vol. 39, No. 3, pp. 575-592.

Myers S. and Majluf N. (1984). "Corporate financing and investment decision when firms have information that investors do not have”, Journal of Financial Economics, Vol. 13, No. 2, pp. 187-221.

Nazlioglu B., Sendurur U., Yanik S. and Özerhan Y. (2012). “The effect of ownership structure on stock prices during crisis periods: A study on ISE 100 index”, International Journal of Business and Social Science, Vol. 3, No. 6, pp. 82-88.

Pindado J., Requejo I. and de la Torre C. (2008). "Does family ownership impact positively on firm value? Empirical evidence from Western Europe”, XVI Finance Forum (Barcelona, Spain).

Pindado J., Requejo I. and de la Torre C. (2011). "Family control and investment-cash flow sensitivity: Empirical evidence from the Euro zone”, Journal of Corporate Finance, Vol. 17, No. 5, pp. 1389-1409.

Schmid T. (2012). “Control considerations, creditor monitoring, and the capital structure of family firms”, Journal of Banking and Finance, Vol. 37, No. 2, pp. 257-262.

Schulze W., Lubatkin M. and Dino R. (2003). "Exploring the agency consequences of ownership dispersion among the directors of private family firms”, Academy of Management Journal, Vol. 46, pp. 179-194.

Schulze W., Lubatkin M., Dino R. and Buchholtz A. (2001). "Agency relationships in family firms: Theory and evidence”, Organization Science, Vol. 12, pp. 99-116.

Villalonga B. and Amit R. (2006). “How do family ownership, control, and management affect firm value?”, Journal of Financial Economics, Vol. 80, pp. 385-417. 